\title{
Pengaruh Dosis Pupuk Kandang dan Jenis Mulsa terhadap Pertumbuhan dan HasiI Tanaman Bawang Merah (Allium ascalonicumL.)
}

\section{Effect of Manure Dosage and Type of Mulch on Growth and Yield of Shallots (Allium ascalonicum $\mathrm{L}$. .)}

\author{
Kalidin $^{1}$, Mardhiah hayati ${ }^{1}$, Trisda kuniawan ${ }^{1}$ \\ Program Studi Agroteknologi PSDKU Gayo Lues, Fakultas Pertanian, Universitas Syiak Kuala.
}

\begin{abstract}
Abstrak. Penelitian bermaksud supaya memahami respon perkembangan serta hasil bawang merah akibat perbedaan takaran pupuk kandang serta jenis mulsa, ada tidaknya interaksi antara takaran pupuk kandang serta bermacam mulsa pada pertumbuhan serta hasil tanam bawang merah. Telah terlaksana di Sektor Timur, kebun percobaan fakultas pertanian universitas syiah kuala, Banda Aceh mulai November sampaike Februari 2021. Rancangan telah dipakai di peneliti ini ialah Rancangan Acak Kelompok (RAK) pola faktorial 3x3 dengan 3 ulangan. Faktor yang diteliti ialah takaran pupuk kandang yang tertara dari 3 taraf yaitu $P_{1}=10$ ton ha ${ }^{-1}\left(1 \mathrm{~kg}\right.$ bedeng $\left.{ }^{-1}\right), \mathrm{P}_{2}=20$ ton ha ${ }^{-1}(2 \mathrm{~kg}$ bedeng $\left.{ }^{-1}\right)$ dan $P_{3}=30$ ton ha ${ }^{-1}\left(3 \mathrm{~kg}\right.$ bedeng $\left.{ }^{-1}\right)$. Faktor kedua adalah jenis mulsa $(\mathrm{M})$ yang terdiri dari 3 taraf yaitu $M_{1}=$ sereh wangi, $M_{2}=$ jerami padi, $M_{3}=$ plastik hitam perak. Didapatkan 9 kombinasi perlakuan pada 3 kali ulangan singa terdapat 27 ulangan riset yang masing-masing tarter dari 5 tanaman sampel. Hasil uji $\mathrm{F}$ menunjukan takaran pupuk kandang ada pengaruh tidak nyata pada tinggi tanaman diumur 2, 4, 6 serta 8 MST, jumlah anakan per rumpun umur 2, 4, 6, serta 8 MST, jumlah perumpun umbi, diameter umbi, berat basah berangkasan umbi per rumpun, berat basah umbi per rumpun, berat kering berangkasan per rumpun, berat umbi kering per rumpun, hasil per plot netto serta potensi hasil tanaman bawang merah.
\end{abstract}

\section{Kata Kunci: Dosis pupuk kandang, jenis mulsa dan tanaman bawang merah.}

\begin{abstract}
The aim of the study was to understand the developmental response and yield of shallots due to differences in the dose of manure and the type of mulch, whether or not there was an interaction between the dose of manure and various mulch on the growth and yield of shallots. It has been implemented in the East Sector, experimental garden of the Faculty of Agriculture, Syiah Kuala University, Banda Aceh from November to February 2021. The design used in this research is a $3 \times 3$ factorial randomized block design (RAK) with 3 replications. The factor studied was the measured amount of manure from 3 levels, namely $\mathrm{P}_{1}=10$ tons ha ${ }^{-1}\left(1 \mathrm{~kg} \mathrm{bed}^{-1}\right), \mathrm{P}_{2}=20$ tons ha ${ }^{-1}\left(2 \mathrm{~kg} \mathrm{bed}^{-1}\right)$ and $\mathrm{P}_{3}=30$ tons ha $^{-1}\left(3 \mathrm{~kg} \mathrm{bed}^{-1}\right)$. The second factor is the type of mulch (M) which consists of 3 levels, namely $\mathrm{M}_{1}=$ citronella, $\mathrm{M}_{2}=$ rice straw, $\mathrm{M}_{3}=$ silver black plastic. There were 9 treatment combinations in 3 replications of the lion, there were 27 research replications, each of which was tarter from 5 sample plants. The results of the $\mathrm{F}$ test showed that the dose of manure had no significant effect on plant height at 2, 4, 6 and $8 \mathrm{WAP}$, number of tillers per clump at 2, 4, 6, and 8 WAP, number of tuber clumps, tuber diameter, tuber root wet weight. per clump, wet weight of tubers per clump, dry weight of dry tubers per clump, dry weight of tubers per clump, yield per net plot and potential yield of shallots.
\end{abstract}

Keywords: Dose of manure, type of mulch and shallots.

\section{PENDAHULUAN}

\section{Latar Belakang}

Bawang merah (Allium ascolanicum L.) yaitu tanaman hortikultura akan memiliki nilai jual di indonesia yang tinggi bawang merah sering dipakai buat bumbu dasar memasak serta industri seperti makanan ringan, mie, instan dan restoran siap saji, sehingga permintaan bawang merah mengalami peningkatan. Bawang merah telah banyak digunakan sebagai penyedap dalam sayuran karena memiliki rasa serta aroma yang khas, juga memiliki kandugan vutamin, gizi, jua banyak membantu pertumbuhan ekonomi masyarakat (Aprlia et al., 2019). Di indonesia hasil produksi bawang merah di tahun 2018 ialah 1,503 juta ton ha ${ }^{-1}$ 
dengan luas lahan 156,8 ribu hektar, dengan produktivitas 9,59 ton ha ${ }^{-1}$. Sedangkan pada tahun 2019 produksi bawang merah meningkat 5,11\% yaitu menjadi 1,580 juta ton dengan luas lahan 159,2 ribu ha ${ }^{-1}$ dengan produktivitas 9,93 ton ha ${ }^{-1}$ (Kementerian Pertanian Republik Indonesia, 2021). Produksi bawang bisa dilakukan melalui caranya seperti memberi pupuk organic serta anorganic, memberikan pupuk kandang paling bagus dipakai perbaikan sipat kimia, fisik, serta biologi tanah serta lebih ramah pada lingkungan. (Pranata, 2020). Memakai pupuk kotoran sapi ada pengaruh paling nyata kepada, jumlah daun pada 14, 28 serta 42 MST serta hasil umbi bawang merah, gabungan perlakuan $100 \mathrm{~g}$ NPK (900 kh ha $\left.{ }^{1}\right)$ serta 2, $4 \mathrm{~kg}$ pupuk kandang (20 ton $\mathrm{ha}^{-1}$ ) menghasilkan pengaruh paling bagus parameter berat kering bragkasan, berat kering umbi serta hasil potensinya, degan memberikan hasilnya 1,22 ton $\mathrm{ha}^{-1}$ ditanaman bawang merah (Salvitia, 2016).

Bahan organik merupakan solusi untuk pengembalian kesuburan pada tanah seperti kotoran lembu, cara menigkatkan suburnya tanah. (Fathurrohman et al., 2015). Interaksi pupuk kandang lembu dengan pupuk $\mathrm{KCl}$, TSP dan Urea mempengaruhi pada pengamatan parameter jumlah umbi dan jumlah daun bawang merah. (Supariadi et al., 2017). Selain mengunakan pupuk, pemberian mulsa juga sangat berdampak terhadap perkembagan dan hasil tanaman bawang merah. Mulsa merupakan bahan untuk penutup tanah agar terjaga dalam kelembapan dan menghambat pertumbuhan gulma. Pemberian mulsa juga menentukan produksi bawang merah yaitu menghasilkan keadaaan yang lebih menguntungkan pada pertumbuhan, penigkatan serta perkembagan jumlah panen. Mulsa juga mempuynyai efek biologi, kimia dan fisik terhadap tanah. (Barus, 2006). Berdasarkan materialnya mulsa juga dapat dibagi dua bagian yakni mulsa organic serta anorganic. Manfaat pemberian mulsa untuk penyediaan zat hara didalam tanah serta mengktifkan kehidupan mikroorganisme didalam tanah, sehingga struktur tanahnya semakin menjadi lebih baik (Roidah, 2013). Mulsa organik adalah sisa tanaman contoh arang sekam, jerami padi, serbuk gergaji, daun bambu, alang-alang, beserta cacahan batang jagung. (sembiring, 2013). Mulsa jerami sreh wangi berasal dari hasil sisa penyulingan minyak sereh wangi yang bisa dijadikan untuk pupuk atau mulsa organik untuk meningkatkan kesuburan tanah. Mulsa jerami sereh wangi bertujuan untuk menekan pertumbuhan gulma di sekitar tanaman, menjaga kekuatan tanahnya dari derasnya air hujan, meninimalkan erosi permukaan tanah (Novayana et al., 2015). Memberi mulsa jerami padi serata mulsa plastik hitam perak bisa menigkatnyan berat umbi basah per ha-1 masing-mssing sebesar 29,3\% serta $24,7 \%$, dibandingkan tampa pemberian mulsa pada tanaman bawang merah (Anshar, 2012).

Mulsa anorganik iyalah mulsa yang diolah dari bahan pabrik, yang sulit untuk terurai seperti mulsa mulsa dari karung plastik, mulsa plastik hitam perak (Doring et al., 2015). Fungsi dari warna plastik hitam perak yakni supaya ada pantulan dari sinaran matahari ketanaman, agar cahaya matahari yang diterima sama daun semakin maksimum sehingga tanaman dapat berfotosintesis dengan baik, kemudian sebahagian hasil dari fotosintesisnya di perlukan kepada membentukan daun pada tanaman (sembiring, 2013) 


\subsection{Waktu dan tempat}

\section{METODOLOGI PENELITIAN}

Sudah dilaksanakan penelitian ini dilahan Sektor Timur, dikebun percoban serta laboratorum ilmu teknologi benih Fakultas Pertanian Universitas Syiah Kuala, Banda aceh mulai dari November 2020 Sampai Februari 2021.

\subsection{AIat dan bahan}

Ada beberapa alat telah dipakai didalam penelitian iyalah cangkul,.parang, garu, meter, jagka srong, talirafia,.timbangan, handphonep/camera srta alat tulis.

\subsubsection{Bahan}

Telah dipakai didalam meneliti ialah bibit bawang merah bima bres sebanyak $2,7 \mathrm{~kg}$. Pupuk pupuk kandang lemu sebanyak $54 \mathrm{~kg}$. Adapun pupuk lain telah dipakai yakni dengan pupuk Urea $270 \mathrm{~g}$, pupuk SP-36 berjumlah 337,5 g serta pupuk KCI berjumlah 337,5 g. Limbah sereh wangi sebanyak $18 \mathrm{~kg}$, jerami padi sebanyak $18 \mathrm{~kg}$ dan mulsa plastik hitam perak sebanyak $9 \mathrm{~m}$. Fungisida Dithane M45 sebanyak 1 bungkus (200 g), Curater 3G 1 bungkus (0,29 g).

\subsection{Rancangan penelitan}

Rancanga yang dipakai didalam meneliti ini ialah rancangan acak klompok (RAK) pola fakror $3 \times 3$ pada 3 ujian paktor telah terteliti yaitu takaran pupuk kotoran sapi yang tertara dari 3 tahap yakni $\mathrm{P}_{1}=10$ ton ha $\mathrm{h}^{-1}\left(1 \mathrm{~kg}\right.$ bedeng $\left.{ }^{-1}\right) \mathrm{P}_{2}=20$ ton $\mathrm{ha}^{-1}\left(2 \mathrm{~kg}\right.$ bedeng $\left.{ }^{-1}\right)$ dan $\mathrm{P}_{3}=30$ ton $\mathrm{ha}^{-1}\left(3 \mathrm{~kg}\right.$ bedeng $\left.{ }^{-1}\right)$ bagian kedua adalah bagian mulsa $(M)$ yang tertara 3 tahap yakni $M_{1}=$ sereh wangi, $M_{2}=$ jerami padi, $\mathrm{M}_{3}=$ pIastik hitem prak. Sehingga dapat 9 kombiasi perulasan karen 3 kali ujian sangga dapat 27 satuan riset yang masing-masing tertara 5 pertanaman sampel.Secara keseluruhannya ada 9 kombinasi perlakuan. Setip perlakuan diulangi banyaknya 3 kali sehingga diperoleh 27 satuan percobaan.

\subsection{PeIaksanaan peneIitian}

\subsubsection{Persiapan lahan}

Pengolahan tanah membersihkan gulma terdahulu terus tanah dicangkul sedalam $30 \mathrm{~cm}$ dengan luas lahan 11,4 m x $4 \mathrm{~m}$, kemudian gumpalan-gumpalan tanah dihancurkan. Setelah pengolahan tanah kemudian pembuatan bedengan dilakukan dengan cara menaikkan tanah dengan menggunakan alat cangkul pada ukuran $1 \mathrm{~m}$ x $1 \mathrm{~m}$, sela antara blok $50 \mathrm{~cm}$, sela antara bedeng blok $30 \mathrm{~cm}$ serta tinggi bedeng $30 \mathrm{~cm}$ sebanyak 27 bedengan.

\subsubsection{Pemupukan}

Pupuk telah dipakai ialah pupuk organik serta anorganik, untuk perlakuan pemberian pupuk organik disebar dengan merata diatas permukaan tanah, kemudian dicangkul sehingga bercampur dengan tanah pemberian dilakukan 7 hari sebelum tanam sehingga pupuk bercampur dengan tanah, kemudian disusul pemupukan annorganik yaitu Urea sebanyak $10 \mathrm{~g} \mathrm{plot}^{-1}$, SP-36 sebanyak 12,5 g plot $^{-1}$ dan $\mathrm{KCl}$ sebanyak $12,5 \mathrm{~g} \mathrm{plot}^{-1}$.

\subsubsection{Pemberian mulsa}

Pemberian mulsa jerami sereh wangi sebanyak $2 \mathrm{~kg}$ bedeng ${ }^{-1}$, mulsa jerami padi sebanyak $2 \mathrm{~kg}$ bedeng ${ }^{-1}$ dan mulsa plastik hitam perak $1 \mathrm{~m}^{\text {bedeng }}{ }^{-1}$. Mulsa jerami diberikan setelah dipotong-potong sepanjang $8 \mathrm{~cm}$ dengan ketebalan $3 \mathrm{~cm}$, mulsa jerami sereh wangi sebanyak $18 \mathrm{~kg}$ mulsa jerami padi $18 \mathrm{~kg}$ serta mulsa plastik hitam perak 9 meter, mulsa diberikan ke lahan 1 hari sebelum bibit bawang merah ditanam. 


\subsubsection{Persiapan bibit}

Bibit bawang merah digunakan bibit telah tersimpan selama 75 hari, ketika umbi kita belah telah nampak bakal daunnya. kemudian bibit yang sama tak terkena hama serta penyakit yang dijadikan untuk bibit, lalu bibit dibersihkan kulit bibit paling luar sama akar umbi yang tinggal. Bagian penghujung umbi bawang merah dipotong $1 / 3$ bagian sama pisau yang bersih bertujuan mempermudah tumbuh tunasanya. Sesudah dipotong bahagian ujungnya, terus dikeringanginkan sampai bekas potongan mengerig untuk menghindari pembusukan di bagian bekas potongan.

\subsubsection{Penanaman}

Penanaman dilaksanakan melalui cara memasukan 1 umbi kedalam lubang tanam memakai sela tanam $20 \mathrm{~cm}$ x $20 \mathrm{~cm}$. Lubang tanam dibuat sama alat tugal, kedalaman lubang rata-rata $3 \mathrm{~cm}$. supaya ujung umbi tampak rata sama tanah.

\subsubsection{Pemeliharaan tanaman.}

pemeliharaan seperti menyiram, menyulam, menyiagkan gulma, dan mengendalikan hama serta penyakit. penyiraman di lakukan dilakukan setiap hari di pagi serta sore hari (sesuai sama kondisi cuaca) menggunakan gempor. cara menyulam menggantikan tanaman bawang merah yang hidup kurang normal ataupun mati sama tanaman yang baru, pada umur 1 minggu penyiangan dilaksana buat membersih rumput liar serta gulma lain yang hidup diareal bedengan caranya mencabuti menggunakan tangan. pengendalian hama serta penyakit di tanaman bawang merah jua dilakukan sama fungisida dithane M-45 konsentrasi $2 \mathrm{~g} \mathrm{l}^{-1}$ air, serta curater $3 \mathrm{~g}$ memakai $2 \mathrm{~g}^{\text {lubang }}{ }^{-1}$

\subsubsection{Panen}

Tanaman bawang merah siap panen setelah umbi bawang merah telah terbentuk ideal, umb sudah muncul di permukaan tanah, persentase bawang sudah tercapai $80 \%$, sebahagian daun berwarna kuning pucat dan sebahagian daun sudah mengering. Pemanenan dilakukan menggunakan tangan, dengan cara mencabut tanaman bawang dari tanah. Panen dilakukan saat tanaman berumur 65 HST.

\subsubsection{Parameter Pengamatan}

Tinggi tanaman $(\mathrm{cm})$ diukur atas 5 tanam sampel yaitu di umur 2, 4, 6, $8 \mathrm{MST}$, tanaman diukur menggunakan meteran dari permukaan tanah yang sudah diberi tanda hingga ujung daun tertinggi. Jumlah anakan per rumpun (anakan). Jumlah anakan perumpun dihitung di tanaman sampel ketika tanaman di umur 2, 4, 6, 8 MST, sama cara menghitung jumlah anakan bawang merah, di setiap rumpun per lubang tanam. Jumlah per rumpun umbi (buah). Jumlah umbi per rumpun ialah jumlah umbi yang dihitung totalitas umbi di tanaman sampel yang dilakukan ketika panen. Diameter umbi $(\mathrm{mm})$. Pengamatan diameter umbi dilaksanakan sesudah panen, caranya menghitung diameter umbi perumpun pakai jangka sorong. Tanaman akan diamati sebanyak 5 umbi persampel. Bobot berangkasan basah per rumpun (g). Berat berangkasan basah per rumpun diamati ketika tanaman bawang merah baru memanen caranya tanaman bawang merah dicabut, serta dibersihin dari tanah yang melekat pada akar batang dan daun. Kemudian bawang merah ditimbang pakai timbang digital. Berat basah umbi per rumpun $(\mathrm{g})$. Penimbangan berat umbi basah dilaksanaka setelah panen untuk dijadikan sampel, dipotong bagian daun bawang merah, terus umbi ditimbang sama menggunakan timbangan digital.

Bobot beragkasan kering daun dan akar perumpun (g). Pengamatan bobot berangkasan kering bawang merah (daun dan akar) dilakukan dengan cara 
dikeringanginkan selama 2 hari dan dimasukan dalam oven dengan suhu $80{ }^{\circ} \mathrm{C}$ lamanya $3 \times 24$ jam sampai mencapai berat konstan dan 5 sampel yang telah dibersihkan setelah panen kemudian menggunakantimb angan digital, berat kering per rumpun umbi ( $\mathrm{g}$ ) berat kering umbi perumpun ditimbang sama cara sesudah umbi dikeringanginkan di dalam ruangan selama satu minggu pada masing-masing sampel. Hasil per plot neto $(\mathrm{g})$ mengamati berat umbi bawang merah per plot netto dilaksanakan melalui cara menimbang semua umbi dari tanaman yang berada di plot neto yakni memakai timbangan. Potensi hasil (ton ha ${ }^{1}$ ) mengamati potensi hasil dilakukan melalui mengkonversikan rata-rata bobot umbi kering kering bawang merah per plot netto caranya memakai rumus seperti dibawah:

Potensi hasil $\left(\right.$ ton $\left.\mathrm{ha}^{-1}\right)=\frac{\text { Luas lahan } 1 \text { ha }-20 \%}{\text { luas plot netto }} \mathrm{x}$ berat umbi plot neto

\section{I. HasiI Penelian}

\section{HASIL DAN PEMBAHASAN}

\section{I.I. Pengaru takaran Pupuk Kandang pada Pertumbuhanserta HasiI Tanaman Bawang Merah}

HasiI uji $\mathrm{F}$ menunjukan bahwa takaran pupuk kandang tak nyata berpengaruh pada tinggi tanaman umur 2, 4, 6 serta 8 MST jumlah anakan perumpun diumur 2, 4, 6 serta 8 MST jumlahi perumpun umbinya, diameter umbinya, berat brangkasan basah umbi perumpun, berat bash umbi perumpn, berat beragkasan kring perumpn, berat kring umbi perumpun, hasil per plot netto serta kapasitas hasil tanam bawang merah.

Tabel 1. Rata-rata bertumbuh bawang merah akibat perlakuan takaran pupuk kandang.

\begin{tabular}{|c|c|c|c|c|c|}
\hline \multirow{2}{*}{\multicolumn{2}{|c|}{ Peubah }} & \multicolumn{3}{|l|}{ Perlakuan } & \multirow{2}{*}{$\mathrm{BNJ}$} \\
\hline & & 10 ton $\mathrm{ha}^{-1}$ & 20 ton $\mathrm{ha}^{-1}$ & 30 ton $\mathrm{ha}^{-1}$ & \\
\hline \multirow{4}{*}{ Tinggi tanaman $(\mathrm{cm})$} & $2 \mathrm{MST}$ & 14,66 & 15,75 & 14,06 & \\
\hline & $4 \mathrm{MST}$ & 18,41 & 20,08 & 20,16 & \\
\hline & $6 \mathrm{MST}$ & 20,65 & 20,76 & 20,70 & \\
\hline & $8 \mathrm{MST}$ & 26,34 & 27,37 & 26,71 & \\
\hline \multirow{4}{*}{$\begin{array}{l}\text { Jumlah anakan perumpun } \\
\text { (anakan) }\end{array}$} & $2 \mathrm{MST}$ & 1,51 & 1,64 & 1,36 & \\
\hline & $4 \mathrm{MST}$ & 3,22 & 3,42 & 2,91 & 0,54 \\
\hline & $6 \mathrm{MST}$ & 3,00 & 3,74 & 3,87 & \\
\hline & $8 \mathrm{MST}$ & 6,22 & 7,33 & 7,36 & \\
\hline \multicolumn{2}{|c|}{ Jumlah umbi per rumpun (umbi) } & 11,04 & 16,04 & 13,82 & \\
\hline \multicolumn{2}{|l|}{ Diameter umbi (mm) } & 21,66 & 21,98 & 22,64 & \\
\hline \multicolumn{2}{|c|}{ Bobot bragkasan basah Per rumpun (g) } & 113,97 & 103,80 & 109,32 & \\
\hline \multicolumn{2}{|c|}{ Bobot basah umbi Per rumpun (g) } & 60,97 & 71,68 & 68,66 & \\
\hline \multicolumn{2}{|c|}{$\begin{array}{l}\text { Bobot berangkasan kering per rumpun } \\
(\mathrm{g})\end{array}$} & 51,11 & 61,40 & 64,50 & \\
\hline \multicolumn{2}{|c|}{ Bobot kering umbi Per rumpun $(\mathrm{g})$} & 41,88 & 42,80 & 39,55 & \\
\hline \multicolumn{2}{|l|}{ Hasil per plot netto $(\mathrm{g})$} & 618,89 & 650,00 & 691,17 & \\
\hline \multicolumn{2}{|l|}{ Potensi hasil (ton ha ${ }^{-1}$ ) } & 13,75 & 14,44 & 15,36 & \\
\hline
\end{tabular}

Tabel 1 menunjukan pada tanaman bawang merah umur 2, 6 serta 8 MST conderong lebih tinggi terdapet ditakaran pupuk kandang 20 ton $\mathrm{ha}^{-1}$, demikian diumur 4 MST conderong lebih tinggi dijmpai ditakaran pupuk kandang 30 ton ha ${ }^{1}$, namuan secara statistik tak bebeda nyata dengen perlakuan takaran pupuk kotoran sapi 10 ton $\mathrm{ha}^{-1}$ serta 30 ton $\mathrm{ha}^{-1}$. Jumlah anakan perumpun tanaman bawang merah diumur 2 serta 4 MST cendrung terbanayak dijumpai diperlakuan 
takaran pupuk kotoran lembu 20 ton $\mathrm{ha}^{-1}$, walau secra statistik tidak berbeda nyata sama jumlah anakan perumpun bawang merah diperlakukan dengan pupuk kotoran sapi takaran 10 ton ha ${ }^{-1}$ seta 30 ton $\mathrm{ha}^{-1}$. Sedagkan diumur 6 dan 8 MST jumIah ankan per rumpun cendrung lebih banyak ditemui memakai takaran pupuk kandang 30 ton ha ${ }^{-1}$, meskipun selaku statistik tak brbeda nayta sama hasil anakan per rumpun bawang merah memberi 10 ton ha ${ }^{-1}$ serta 20 ton ha ${ }^{-1}$ takaran pupku kandang. Jumlah umbi per rumpun cenderung terbanayak didapatkan megunakan takaran pupuk kotoran sapi 20 ton $\mathrm{ha}^{-1}$ walaupun secara statistik berbeda tidak nyata sama jumlah per rumpu umbinya bawang merah yang diberi pupuk kandng 10 ton ha $^{-1}$ serta 30 ton ha ${ }^{-1}$.

Diameter umbi tanaman bawang merah cendrung lebih besar dijumpai atas perluasan takaran pupuk kandang 30 ton $\mathrm{ha}^{-1}$, namun scara statistik tidak berbeda nyata dengan diametr umbi tanaman bawang merah mengguna takaran pupuk kotoran sapi 10 ton ha ${ }^{-1}$ serta 20 ton $\mathrm{ha}^{-1}$. Merat berangkasan basah per rumpun tanam bawang merah cendarung lebih berat ditemui diperlakuan takaran pupuk kotoran lembu 10 ton $\mathrm{ha}^{-1}$, namun cara statistika tak nayata tak beda dengan bobot berangkasan basah per rumpun tanaman bawang merah, takaran memakai pupuk kandang adalah 20 ton ha ${ }^{-1}$ serta 30 ton ha ${ }^{-1}$. Berat basah umbi per rumpun tanaman bawang merah cenderung lebih berat didapatkan di perlakuan takaran pupuk kotoran lembu 20 ton ha $^{-1}$, tetapi cara statistika tidak ada perbedaan nyatanya dibobot basah umbi perumpun bawang merah yang diberi takaran pupuk kotoran sapi 10 ton $\mathrm{ha}^{-1}$ serta 30 ton ha $\mathrm{ha}^{-1}$. Berat berangkasan kering per rumpun tanaman bawang merah cenderung makin berat yaitu diperlakuan takaran pupuk kandang 30 ton $\mathrm{ha}^{-1}$, namun cara statistika ternyata ada perbedaan sama bobot berangkasan kerig per rumpun tanaman bawang merah perlakuan dosis pupuk kandang 10 ton ha ${ }^{-1}$ serta 20 ton $\mathrm{ha}^{-1}$. Berat umbi kering per rumpun tananman bawang merah cendrung semakin berat ditemukan di perlakuan takaran pupuk kotoran lembu 20 ton $\mathrm{ha}^{-1}$, tetapi cara statistika nyata tak berbeda sama bobot kering umbi per rumpun bawang merah telah diberi takarn pupuk kandang 10 ton ha ${ }^{-1}$ serta 30 ton ha ${ }^{-1}$.

Hasil per plot netto tanaman bawang cenderung lebih tinggi ditemukan di perlakuan takaran pupuk kandang 30 ton $\mathrm{ha}^{-1}$, namun seara statistik tak beda nayata sama hasil per plot netto tanaman bawang merah perlakuan takaran pupuk kandang 10 ton ha ${ }^{-1}$ serta 20 ton ha ${ }^{-1}$. potensi hasil tanaman bawang merah cendrung lebih tingi terdapat diperlakuan takaran pupuk kandang 30 ton ha ${ }^{-1}$, namun cara statistika nyata sama potensi hasil tanaman bawang merah perlakuan takaran pupuk kandang10 ton ha ${ }^{-1}$ serta 20 ton $\mathrm{ha}^{-1}$.

\subsubsection{Pengaruh Jenis Mulsa terhadap Prtumbuhan dan HasiI Tanaman Bawang Merah.}

Hasil uji $\mathrm{F}$ menunjukkan yakni takaran pupuk kandang ada pengaruh tak nyata pada tinggi tanaman diumur 2, 4, 6 serta 8 MST, jumlah anakan per rumpun umur 2, 4, 6 serta 8 MST, jumlah umbi per rumpun, diameter umbi, berat berangkasan basah umbi per rumpun, berat basah umbi per rumpun, berat berangkasan kering per rumpun, berat kering umbi per rumpun, hasil per plot netto serta potensi hasilnya tanaman bawang merah.

Tabel 2. Rata-rata pertumbuhan bawang merah akibat memakai pengaruh jenis mulsa 


\begin{tabular}{|c|c|c|c|c|c|}
\hline & & & Perlakua & & \\
\hline Peubah & & $\begin{array}{c}\text { Jerami sereh } \\
\text { wangi }\end{array}$ & $\begin{array}{l}\text { Jerami } \\
\text { padi }\end{array}$ & $\begin{array}{c}\text { Plastik hitam } \\
\text { perak }\end{array}$ & $\mathrm{BNJ}$ \\
\hline & $2 \mathrm{MST}$ & 14,43 & 15,58 & 14,47 & \\
\hline Tingoi tanaman $(\mathrm{cm})$ & $4 \mathrm{MST}$ & 20,27 & 19,08 & 19,29 & \\
\hline 11nggi tanaman $(\mathrm{cm})$ & $6 \mathrm{MST}$ & 21,17 & 20,52 & 20,42 & \\
\hline & $8 \mathrm{MST}$ & 26,52 & 26,71 & 27,18 & \\
\hline & $2 \mathrm{MST}$ & 2,29 & 2,36 & 2,44 & \\
\hline Jumlah anakan perumpun & $4 \mathrm{MST}$ & 3,07 & 3,27 & 3,22 & 0,54 \\
\hline (anakan) & $6 \mathrm{MST}$ & 3,38 & 3,24 & 3,99 & \\
\hline & $8 \mathrm{MST}$ & 6,73 & 6,78 & 7,40 & \\
\hline Jumlah umbi per rumpun & & 13,76 & 13,49 & 13,67 & \\
\hline Diameter umbi (mm) & & 21,87 & 21,50 & 22,91 & \\
\hline Bobot bragkasan basah Per & $(\mathrm{g})$ & 96,76 & 88,39 & 141,94 & \\
\hline Bobot basah umbi Per rum & & 62,82 & 61,99 & 76,49 & \\
\hline Bobot berangkasan kering & $\operatorname{apun}(\mathrm{g})$ & 41,06 & 39,98 & 43,17 & \\
\hline Bobot kering umbi Per rum & & 52,70 & 56,01 & 68,30 & \\
\hline Hasil per plot netto $(\mathrm{g})$ & & 646,67 & 537,78 & 775,61 & \\
\hline Potensi hasil (ton ha-1) & & 14,37 & 11,95 & 17,24 & \\
\hline
\end{tabular}

Tabe1 2 tanaman bawang merah di umur 2, 6 serta 8 MST cenderung lebih tinggi dijumpai di takaran pupuk kandang 20 ton ha- ${ }^{-1}$, sedemikian di umur 4 MST conderong lebih tinggi dijumpai di takaran pupuk kotoran lembu 30 ton ha ${ }^{-1}$, meski cara statistika nyata tak berbeda sama perlakuan takaran pupuk kotoran sapi 10 ton $\mathrm{ha}^{-1}$ serta 30 ton ha ${ }^{-1}$. jumlah anakan per rumpun tanaman bawang merah umur 2 dan 4 MST cenderung paling banyak ditemuikan diperlakuan takaran pupuk kandang 20 ton ha ${ }^{-1}$, meski cara statistika tak berbeda nyat dengan jumlah anakan per rumpun tanaman bawang merah perlakuan takaran pupuk kotoran lembu 10 ton ha $^{-1}$ serta 30 ton $\mathrm{ha}^{-1}$. Sedemikian di umur 6 serta 8 MST jumlah anakan per rumpun cenderung lebih banyak dijumpai di perlakuan takaran pupuk kandang 30 ton $\mathrm{ha}^{-1}$, meskipun cara statistika nyata tak berbeda sama jumlah anakan per rumpun tanaman bawang merah pakai takaran pupuk kotoran lembu 10 ton ha' $\mathrm{harta}^{-1} 20$ ton ha ${ }^{-1}$.

Jumlah umbi per rumpun tanaman bawang merah cenderung lebih banyak ditemui di perlakuan takaran pupuk kandang 20 ton ha ${ }^{-1}$ meski cara statistika berbeda tak nyata sama jumlah umbi per rumpun tanaman bawang merah perluasan takaran pupuk kandang 10 ton $\mathrm{ha}^{-1}$ serta 30 ton $\mathrm{ha}^{-1}$. Diameter umbi tanam bawang merah conderong paling besar ditemukan di perlakuan takaran pupuk kotoran lembu 30 ton ha $^{-\mathrm{I}}$, namun cara statistika tak beda nyata sama diameter umbi tanaman bawang merah memakai takaran pupuk kandang 10 ton ha ${ }^{-\mathrm{I}}$ serta 20 ton ha $\mathrm{h}^{\mathrm{I}}$. Berat berangkasan basah per rumpun tanaman bawang merah conderong paling berat ditemui di perlakuan takaran pupuk kotoran lembu 10 ton ha ${ }^{-\mathrm{I}}$, namun cara statistika beda tak nyata sama bobot berangkasan basah per rumpun tanaman bawang merah perlakuan takaran pupuk kotoran lembu 20 ton ha ${ }^{-1}$ serta 30 ton $\mathrm{ha}^{-1}$. Bobot basah umbi per rumpun tanaman bawang merah cenderung lebih berat dijumpai pada perlakuan takaran pupuk kandang 20 ton $\mathrm{ha}^{-1}$, namun secara statistik berbeda tidak nyata dengan bobot basah umbi per rumpun tanaman bawang merah perlakuan takaran pupuk kandang 10 ton $\mathrm{ha}^{-1}$ dan 30 ton ha ${ }^{-1}$ bobot berangkasan kering per rumpun tanaman bawang merah conderong paling berat ditemui di perlakuan takaran pupuk kandang 30 ton $\mathrm{ha}^{-1}$, namun cara statistika beda tak nyata sama bobot berangkasan kering per rumpun tanam bawang merah memakai dosis pupuk kotoran lembu 10 ton ha ${ }^{-1}$ serta 20 ton ha ${ }^{-1}$. Bobot kering umbi per rumpun tanaman bawang merah conderong paling terberat ditemui di perlakuan takaran pupuk 
kotoran lembu 20 ton $\mathrm{ha}^{-1}$, namun cara statistika beda tak nyata sama berat umbi per rumpun kering tanaman bawang merah memakai takaran pupuk kotoran lembu 10 ton ha ${ }^{-1}$ serta 30 ton ha ${ }^{-1}$.

Hasil per plot netto tanaman bawang conderong tertingi ditemui di pemakaian takaran pupuk kotoran sapi 30 ton ha ${ }^{-1}$, meski cara statistika nyata tak berbeda sama hasil per plot netto tanaman bawang merah perlakuan takaran pupuk kotoran lembu 10 ton $\mathrm{ha}^{-1}$ dan 20 ton ha ${ }^{-1}$. potensi hasil tanaman bawang merah conderong paling tinggi ditemui di perlakuan takaran pupuk kotoran lembu 30 ton $\mathrm{ha}^{-1}$, namun cara statistika beda tak nyata sama potensi hasil tanaman bawang merah memakai takaran pupuk kandang 10 ton $\mathrm{ha}^{-1}$ serta 20 ton ha ${ }^{-1}$

\subsubsection{Pengaru Interaksi ditakaran Pupuk Kandang Dengan Jenis MuIsa pada Pertumbuhan serta HasiI Tanamam Bawang Merah.}

Hasil Penelitian mengarahkan ada interaksi yang nyata antara takaran pupuk kandang sama jenis mulsa tanaman bawang merah pada jumlah anakan per rumpun diumur 4 MST, serta ada interaksi yang tak nyata pada tinggi tanaman umur 2, 4, 6 serta 8 MST jumlah anakan per rumpun 2, 4, 6 serta 8 MST jumlah umbi per rumpun, diameter umbi, berat basah umbi brangkasan per rumpun, berat umbi basah per rumpun, berat kering berangkasan per rumpun, berat umbi kering per rumpun, hasil per plot netto serta potensi hasil tanaman bawang mera pada Tabel 3 . Tebel 3. Rata-rata jum1ah anakan per rumpun (anakan) umur 4 MST bawag merah akibat perlakuan takaran pupuk kandang dengan bermacam mu1sa

\begin{tabular}{lccc}
\hline \multirow{2}{*}{$\begin{array}{c}\text { Perlakuan Dosis Pupuk } \\
\text { Kandeng (ton ha }\end{array}$} & \multicolumn{3}{c}{ Perlakuan Jenis Mulsa } \\
\cline { 2 - 4 } & $\begin{array}{c}\text { Jerami sereh } \\
\text { wangi }\end{array}$ & Jerami padi & $\begin{array}{c}\text { Plastik hitam } \\
\text { perak }\end{array}$ \\
\hline 10 ton ha $^{-1}$ & $3,07 \mathrm{Aa}$ & $2,80 \mathrm{Aa}$ & $3,80 \mathrm{Bb}$ \\
$20{\text { ton } \mathrm{ha}^{-1}}^{\text {non }}$ ton $^{-1}$ & $3,00 \mathrm{Aa}$ & $4,27 \mathrm{Ab}$ & $3,00 \mathrm{Aa}$ \\
\hline
\end{tabular}

$\mathrm{BNJ}_{0,05}$ 0.54

Keteranagan : Angka akan diikuti sama huruf yang menyama (huruf kapital dibaca cara horizontal serta huruf kecil dibaca cara vertikal) tak berbeda nyat di $\mathrm{BNJ}_{0.05}$.

Tabel 3 manunjukkan bahwa perlakuan pupuk kotoran sapi 10 toh ha ${ }^{-1}$ sama pemberian mulsa memperlihatkan bahwa jumlah anakan per rumpun paling baik ditemui di mulsa plastik hitam perak akan pasti berbeda sama pemakaian mulsa jerami sereh wangi serta mulsa jerami padi. Pada pupuk kandang 20 ton ha ${ }^{-1}$ dengan penggunaan mulsa memperlihatkan jumlah anakan per rumpun cenderung lebih banyak dijumpai pada mulsa jerami padi, walapun secara statistik berbeda tidak nyata dengan pelakuan jenis mulsa jerami sereh wangi serta mulsa plastik hitam perak. Pada pupuk kandang 30 ton ha $^{-1}$ dengan penggunaan mulsa memperlihatkan jumlah anakan per rumpun cenderung lebih banyak dijumpai pada mulsa jerami sereh wangi yang berbeda tidak nyata dengan pemakaian mulsa jerami padi serta mulsa plastik hitam perak. Penggunaan mulsa jerami sereh wangi pada jumlah anakan per rumpun umur 4 MST cenderung lebih banyak terdapat di takaran pupuk kotoran lembu 30 ton $\mathrm{ha}^{-1}$, meski cara statistika tak berbeda nayat sama perlakuan takaran pupuk kotoran lembu 10 serta 20 ton ha ${ }^{-1}$. Sedangkan di perlakuan mulsa jerami padi jumlah anakan per rumpun terbanyak terdapat di takaran pupuk kotoran sapi 20 ton $\mathrm{ha}^{-1}$ beda tak nyata sama perlakuan takaran pupuk kotoran sapi 10 dan 30 ton $\mathrm{ha}^{-1}$. sama mulsa plastik hitam perak jumlah anakan per rumpun terbanyak terdapat di takaran pupuk kandang 10 ton $\mathrm{ha}^{-1}$ serta tak beda nyata sama perlakuan takaran pupuk kandang 20 ton ha ${ }^{-1}$ serta ton $\mathrm{ha}^{-1}$. 


\section{KESIMPULAN}

\subsection{Kesimpulan}

Takaran pupuk kandang ada pengaruh tak nyata pada tinggi tanaman di umur 2, 4, 6 serta 8 MST, jumlah anakan per rumpun diumur 2, 4, 6 serta 8 MS jumlah per rumpun umbi, diameter umbi, berat basah brangkasan umbi per rumpun, berat basah umbi per rumpun, berat berangkasan kering per rumpun, berat kering umbi per rumpun, hasil per plot netto serta potensi hasil tanaman bawang merah. Tumbuh serta hasil tanaman bawang merah conderong palig baik dtemu di takaran pupuk kandang 30 ton $\mathrm{ha}^{-1}$. Jenis mulsa berpengaruh tak nyata terhadap tinggi tanaman di umur 2, 4, 6 serta 8 MST, jumlah anakan per rumpun umur 2, 4, 6 sera 8 MST jumlah umbi per rumpun, diameter umbi, berat berangkasan basah umbi per rumpun, berat basah umbi per rumpun, berat berangkasan kering per rumpun, berat kering umbi per rumpun, hasil per plot netto serta potensi hasil tanaman. Pertumbuhan serta hasil tanaman bawang merah cenderung lebih baik di temi di pemberian mulsa plastik hitam perak. Di temukan interaksi nyata antara dosis pupuk kandang dengan jenis mulsa tanaman bawang merah terhadap jumlah anakan per rumpun umur 4 MST. Jumlah anakan per rumpun tanaman bawang merah lebih banyak ditemui di kombinasi takaran pupuk kandang 10 ton ha ${ }^{-1}$ dengan mulsa plastik hitam perak.

\subsection{Saran}

Penting dilaksanakan penelitian lebih lanjut tujuan memperluas pemahaman tentang takaran pupuk kandang serta bermacam mulsa pada pertumbuhannya serta hasil tanaman bawang merah.

\section{DAPTAR PUSTAKA}

Aprlia, F. R., G. Sumarto dan E. W. Tini. 2019. Pertumbuhan dan hasil bawang daun (Allium fistulosum L.) Pada jarak tanam dan pemotongan bibit yang berbeda. J. Penelitian Tanaman Terpaan. 19(1): 11-18.

Ansar, M. 2012. Pertumbuhan dan Hasil Bawang Merah Pada Keragaman Ketinggian Tempat. Disertasi. Universitas Gadjah Mada.Yogyakarta.

Barus, W. A. 2006. Perumbuhan dan Produksi Cabai (Capsicum annum L.) Dengan Penggunaan Mulsa Dan Pemupukan PK. J. Penelitian Bidang Ilmu Pertanian 4(1): 41-44.

Doring, T., U. Heambach, T. Thieme, M. Finckh dan H. Sauce. 2015. Aspek mulsa jerami bahan organik, dampaknya terhadap iklim mikro. J. Agronomi Indonsia. 48(1): 52-58.

Fathurrohman, A., M. Anir, A. Zukriyah dan M. A. Adam. 2015. Persepsi peternak sapi dalam pemanfaatn kotoran sapi menjadi bio-gas di Desa Sekarmojo Purwosari Pasuruan. Jurnal Ilmu-Ilmu Peternakan. 25(2): 36-42.

Kementrian Pertanian Republik Indonesia. 2021. Produksi bawang merah. httpas// www.pertanian.go.id/Produksi dan Produktivitas Hortikultura Indonesia. J akarta. (Diakses 12 Juli 2021). 
Novayana, D., Sipayung, R., dan Barus, A. 2015. Respons pertumbuhan dan produksi bawang merah (Allium ascalonicum L.) Terhadap jenis mulsa dan pupuk kandang ayam. Fakultas Pertanian. USU. Medan. Jurnal Online Agroekoteknologi. 3(2): 446-457.

Pranata, A. S. 2010. Tip Jitu Bertanam 16 Tanaman Buah dan Sayur. Agromedia, Jakarta

Roidah, I. S. 2013. Manpaat penggunaan pupuk organik untuk kesuburan tanah. Jurnal Universitas Tulungagung Bonorowo. 1(1): 30-24.

Salvitia, D. 2016. Respon pertumbuhan dan hasil bawang merah (Allium ascalonicum L.) Terhadap kombinasi dosis NPK dan dosis pupuk kandang. Jurnal Ilmiah Mahasiswa Pertanian Unsyiah-AGT. 1(1): 217-226.

Sembiring, A. P. 2013. Pemanfaatan mulsa plastik hitam perak (MPHP) dalam budidaya cabai (Capsicum annuum L.) http://www.scribd.com/dok/820003 78/Pemanfaatan mulsa-plastik-hitam-perak-MPHP-dalam-budidaya-cabaiCapsicum-annuum.

Supariadi, Y., Yetti dan S. Yoseva. 2017. Pengaruh pemberian pupuk kandang dan pupuk $\mathrm{N}, \mathrm{P}$ dan $\mathrm{K}$ terhadap pertumbuhan dan produksi tanaman bawang merah (Allium ascalonicum L.) Jurnal Online Mahasiswa. 4(1): 1-12. 